\title{
ANALISIS KADAR TOTAL FLAVONOID DAN UJI AKTIVITAS ANTIOKSIDAN EKSTRAK DAUN KELUBUT (Passiflora foetida L.)
}

\author{
Arief Fadillah*, Agung Rahmadani, Laode Rijai \\ Laboratorium Penelitian dan Pengembangan FARMAKA TROPIS Fakultas \\ Farmasi Universitas Mulawarman, Samarinda, Kalimantan Timur \\ *Email: arieffadillah81@yahoo.com
}

\begin{abstract}
ABSTRAK
Dilakukan penelitian dengan judul Analisis Kadar Total Flavonoid dan Uji Aktivitas Antioksidan Ekstrak Daun Kelubut (Passiflora foetida). Penelitian ini bertujuan untuk mengetahui kandungan total flavonoid serta potensi antioksidan ekstrak daun kelubut (Passiflora foetida). Pengujian kandungan total flavonoid menggunakan metode spektrofotometri UV-Vis dengan pereaksi dan alumunium klorida, gambaran hasil flavonoid yaitu menggunakan ekuivalen kuersetin sebagai standar. Sedangkan pengujian aktivitas antioksidan dilakukan dengan menggunakan metode DPPH dan gambaran aktivitas antioksidan yaitu dinyatakan dengan $\mathrm{IC}_{50}$. Hasil yang didapat lalu dihitung dengan menggunakan analisis data regresi linier. Hasil kadar total flavonoid tertingi terdapat pada fraksi etil asetat sebesar $5.44 \mathrm{mg}$ QE/g dan hasil uji aktivitas antioksidan ekstrak daun kelubut $(P$. foetida) berpotensi sedang yang terdapat pada fraksi etil asetat sebesar 105.840 ppm.
\end{abstract}

Kata Kunci: Passiflora foetida, total flavonoid, antioksidan, kelubut

\section{PENDAHULUAN}

Usaha pengembangan tanaman untuk pengobatan perlu dilakukan mengingat bahwa tanaman mudah diperoleh dan murah. Tetapi penggunaan tanaman untuk pengobatan perlu ditunjang oleh data penelitian dari tanaman tersebut sehingga khasiatnya tidak diragukan lagi dan dapat dipertanggungjawabkan secara ilmiah.

Makhluk hidup akan mengalami proses menjadi tua secara alamiah. Proses tua terkadang terjadi lebih cepat daripada biasanya karena adanya proses penuaan dini. Faktor penyebab terjadinya proses penuaan dini salah satunya disebabkan oleh radikal bebas (Maulana et al., 2016). Oleh sebab itu dibutuhkannya antioksidan sebagai senyawa yang melindungi sistem biologis terhadap efek berpotensi 
berbahaya dari proses atau reaksi yang dapat menyebabkan oksidasi yang berlebihan akibat radikal bebas.

Antioksidan merupakan dasar dari banyak fungsi biologis lainnya, seperti anti-kanker, anti-inflamasi dan anti-penuaan. Lebih lanjut pencegahan penyakit kronis lain, seperti kanker, diabetes dan penyakit kardiovaskular dihubungkan dengan aktivitas antioksidan (Zou et al., 2015).

Salah satu tanaman yang berpotensi sebagai tanaman obat yang hingga saat ini masih belum dimanfaatkan ialah kelubut $(P$. foetida). Daun kelubut $(P$. foetida) dapat dijadikan sumber yang baik dalam pengobatan alternatif penyakit rematik, inflamasi, sakit perut dan diare (Assadujjaman et al., 2014). Manfaat terhadap banyak kondisi ini timbul sebagian melalui karakteristik antioksidan senyawa golongan flavonoid. Senyawa flavonoid memiliki potensi sebagai antioksidan karena memiliki gugus hidroksil yang terikat pada karbon cincin aromatik sehigga dapat menangkap radikal bebas yang dihasilkan dari reaksi peroksidasi lemak (Dewi et al., 2014). Oleh karena itu, penting untuk mengidentifikasi dan mengukur senyawa tersebut sebagai antioksidan. Mengingat pentingnya fungsi senyawa flavonoid maka penelitian kadar flavonoid total yang terkandung dalam tumbuhan kelubut perlu dilakukan. Dengan demikian pemanfaatan tumbuhan kelubut dapat lebih dijadikan sebagai alternatif pengobatan herbal serta penggunaanya dapat dipertanggungjawabkan oleh masyarakat.

\section{BAHAN DAN METODE}

Bahan yang digunakan dalam penelitian meliputi Ekstrak Daun Kelubut ( $P$. foetida), Aquades, $\mathrm{AlCl}_{3}, \mathrm{DPPH}$, Etil Asetat, Kuersetin, Metanol, $\mathrm{NaNO}_{2}, \mathrm{NaOH}$, n-Butanol dan n-Heksana.

\section{Ekstraksi Senyawa}

Sampel yang telah kering, dimaserasi dengan menggunakan pelarut metanol selama 2x24 jam dan dilakukan ekstrak berulang-ulang hingga larutan ekstrak tidak berwarna lagi. Selanjutnya, ekstrak tersebut disaring dan pelarut diuapkan dengan rotary evaporator sehingga diperoleh ekstrak kasar metanol. 


\section{Fraksinasi}

Ekstrak kasar metanol difraksinasi berdasarkan perbedaan tingkat kepolaran pelarut-pelarut organik. Pertama yang dilakukan ekstrak kasar sebanyak 10 gram dilarutkan dengan air selanjutnya difraksinasi dengan $n$-heksana di dalam corong pisah, hingga diperoleh 2 fraksi, yaitu fraksi metanol-air dan fraksi $n$-heksana. Fraksi $n$-heksana diuapkan dan disebut ekstrak fraksi $n$-heksana. Selanjutnya fraksi metanol-air difraksinasi dengan penambahan etil asetat. Dari fraksinasi kedua ini diperoleh 2 fraksi, yaitu fraksi etil asetat dan fraksi metanol-air. Dilakukan fraksinasi kembali fraksi metanol-air dengan menggunakan nbutanol. Sehingga akan diperoleh fraksi tak larut dan fraksi n-butanol. Kemudian ketiga fraksi tersebut diuapkan dan hasilnya masing-masing disebut fraksi nheksana, fraksi etil asetat dan fraksi n-butanol.

\section{a. Penentuan Kadar Flavonoid Total}

Kandungan flavonoid total ditentukan secara spektrofotometri visibel sesuai dengan Zou dalam Rohman (2007) yaitu sejumlah ekstrak atau fraksi uji dimasukkan dalam labu takar $10 \mathrm{~mL}$, ditambah $4 \mathrm{~mL}$ aquades dan 0,3 mL larutan $\mathrm{NaNO}_{2}$, lalu dibiarkan selama 6 menit. Setelah itu larutan ditambah dengan 0,3 mL $\mathrm{AlCl}_{3} 10 \%$ dan dibiarkan selama 5 menit. Larutan selanjutnya ditambah $4 \mathrm{~mL}$ $\mathrm{NaOH} 10 \%$ dan aquades sampai $10 \mathrm{ml}$. Larutan dibiarkan selama 15 menit dan selanjutnya dibaca absorbansinya pada panjang gelombang $510 \mathrm{~nm}$, terhadap blangko yang terdiri atas semua pereaksi yang digunakan akan tetapi tidak mengandung kuersetin atau sampel uji. Kandungan flavonoid total dinyatakan sebagai gram ekuivalen kuersetin tiap 100 gram subfraksi (\% b/b EK).

\section{d. Uji Aktivitas Antioksidan}

Ekstrak dan fraksi uji dilarutkan dengan pelarut metanol dan dibuat dalam berbagai konsentrasi, kemudian ditambah $2 \mathrm{~mL}$ larutan DPPH yang dibuat dengan konsentrasi 40 ppm kedalam tabung reaksi, dilakukan homogenisasi menggunakan vortex dan dibiarkan pada tempat gelap selama 30 menit pada suhu kamar. Sebagai blanko digunakan metanol dan DPPH tanpa penambahan ekstrak atau fraksi uji. Selanjutnya diukur absorbansinya pada $\lambda$ maksimum. Data yang diperoleh digunakan. melalui pengujian terhadap peredaman radikal bebas DPPH yang 
dinyatakan dalam absorbansi yang kemudian dianalisis dengan regresi linear untuk menentukan nilai $\mathrm{IC}_{50}$.

\section{HASIL DAN PEMBAHASAN}

Penentuan kandungan senyawa flavonoid total bertujuan untuk mengetahui kandungan senyawa flavonoid yang terkandung didalam ekstrak daun kelubut. Penentukan kadar senyawa flavonoid total pada sampel dinyatakan dalam gram ekuivalen kuersetin tiap gram subfraksi (b/b QE) (Rohman et al., 2007). Penentuan jumlah flavonoid dari ekstrak daun kelubut dilakukan dengan kolorimetri komplementer yang mempunyai prinsip pengukuran berdasarkan pembentukan warna. Prinsip penetapan flavonoid dengan metode kolorimetri $\mathrm{AlCl}_{3}$ adalah pembentukan kompleks, sehingga terjadi pergeseran panjang gelombang ke arah visible (nampak) yang ditandai dengan larutan menghasilkan warna yang lebih kuning. $\mathrm{AlCl}_{3}$ akan bereaksi dengan gugus keto pada $\mathrm{C} 4$ dan gugus $\mathrm{OH}$ pada $\mathrm{C} 3$ atau C5 pada senyawa flavon atau flavonol membentuk senyawa kompleks yang stabil (Anwar, 2016) Sehingga metode ini dapat digunakan untuk menentukan jumlah flavonoid golongan flavon dan flavonol. Reaksi pembentukan kompleks antara $\mathrm{AlCl}_{3}$ dengan flavonol dapat dilihat pada Gambar 6.1. dan reaksi pembentukan kompleks antara $\mathrm{AlCl}_{3}$ dengan flavon dapat dilihat pada Gambar 6.2. berikut:

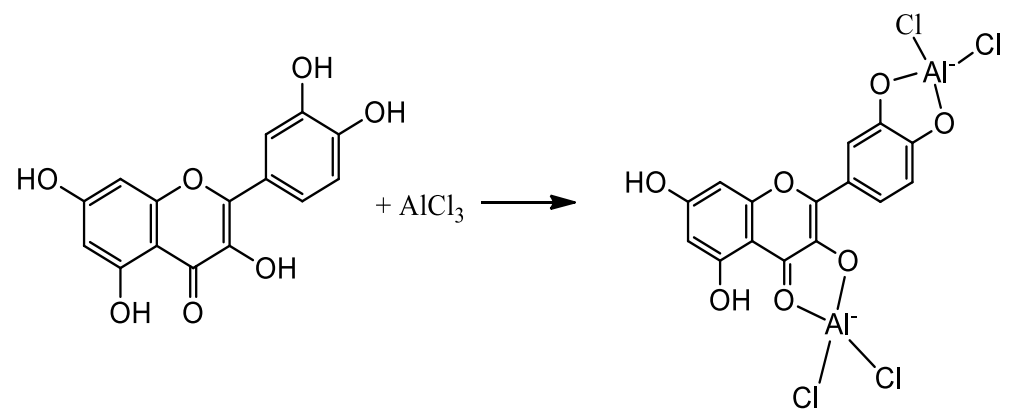

Gambar 6.1. Reaksi pembentukan kompleks antara $\mathrm{AlCl}_{3}$ dengan flavonol 


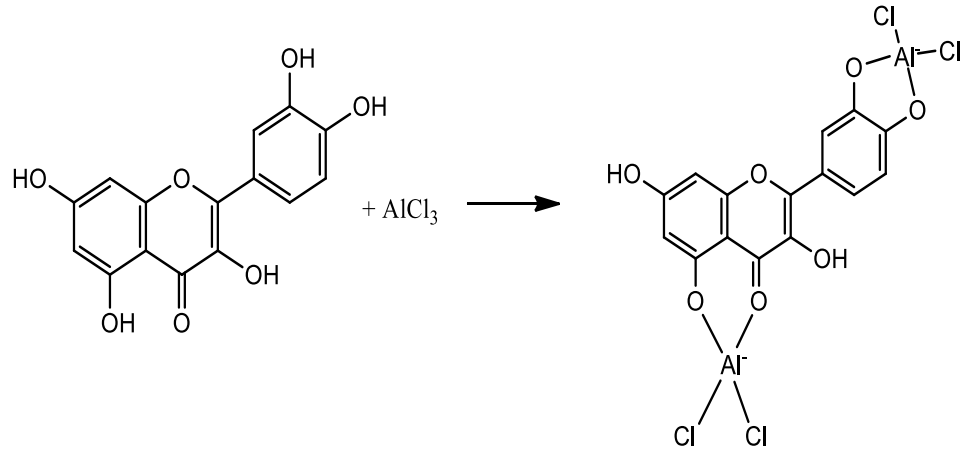

Gambar 6.2. Reaksi pembentukan kompleks antara $\mathrm{AlCl}_{3}$ dengan flavon (Manarim dan De Agular, 2016)

Penggunaan $\mathrm{NaNO}_{2}$ dan $\mathrm{NaOH}$ akan membentuk suatu kompleks sistem $\mathrm{NaNO}_{2}-\mathrm{AlCl}_{3}-\mathrm{NaOH}$ yang menunjukkan warna khusus yang didasarkan pada reaksi ion aluminium dengan flavonoid pada suasana basa membentuk senyawa kompleks (Zhu et al., 2009).

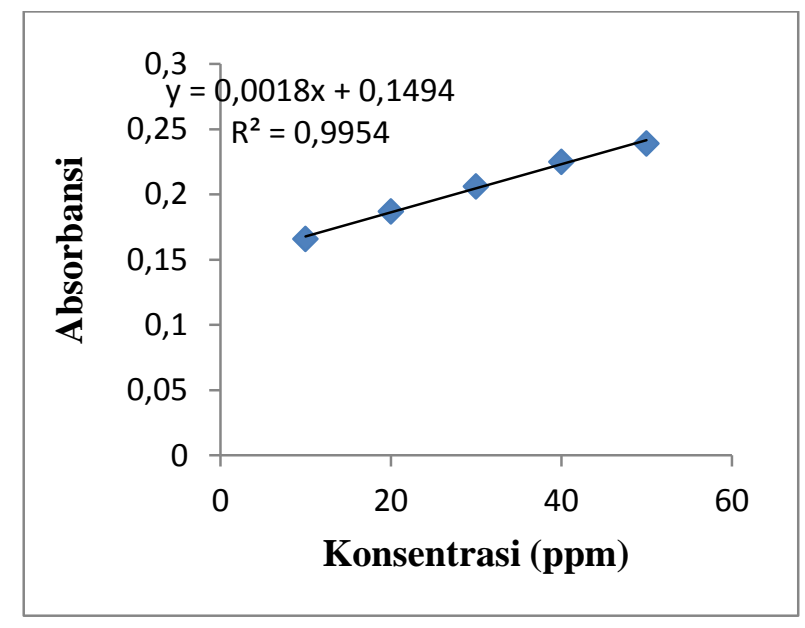

\section{Grafik 1. Kurva standar kuersetin}

Pada pembuatan kurva kalibrasi dengan metode $\mathrm{AlCl}_{3}$ digunakan kuersetin sebagai pembanding karena kuersetin merupakan flavonoid golongan flavonol yang mempunyai gugus keto pada C-4 dan memiliki gugus hidroksi pada atom C-3 atau C-5 yang bertetangga dari flavon dan flavonol (Azizah, 2014).

Absorbansi dari kuersetin yang didapat kemudian diplot terhadap konsentrasi untuk mendapatkan persamaan kurva kalibrasi. Persamaan yang diperoleh yaitu y 
$=0,001 \mathrm{x}+0,149$ dengan koefisien korelasi $\left(\mathrm{R}^{2}\right)=0,995$. Nilai $\mathrm{R}^{2}$ atau koefisien korelasi yang mendekati 1 menunjukkan analisis regresi yang paling dapat dipercaya. Kurva standar kuersetin dapat dilihat pada Grafik 1.

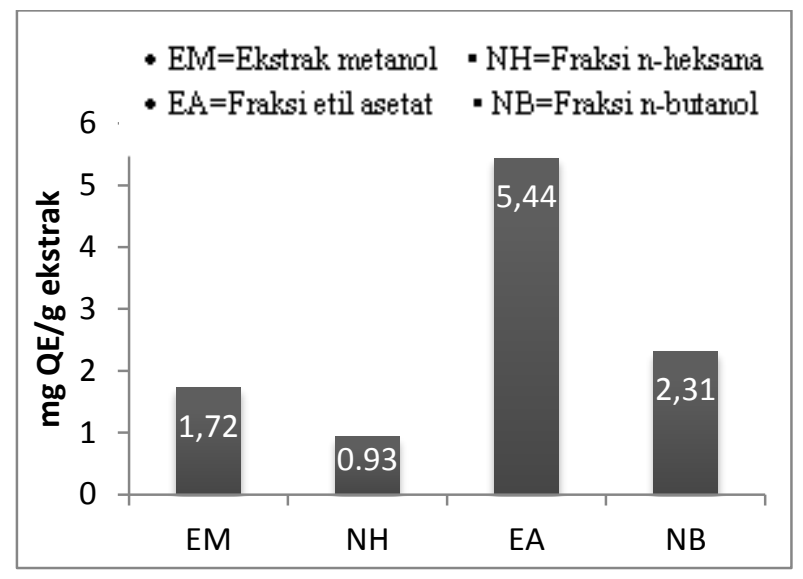

Grafik 2. Kadar total flavonoid pada ekstrak dan fraksi daun kelubut

Hasil penelitian, pada grafik 2, menunjukkan bahwa untuk sampel daun kelubut, konsentrasi senyawa flavonoid tertinggi adalah pada fraksi etil asetat sebesar $5.44 \mathrm{mg} \mathrm{QE} / \mathrm{g}$, diikuti oleh fraksi n-butanol dan ekstrak metanol berturutturut sebesar $2.31 \mathrm{mg}$ QE/g dan $1.72 \mathrm{mg}$ QE/g. Konsentrasi flavonoid terendah adalah terdapat pada fraksi n-heksana sebesar $0.936 \mathrm{mg}$ QE/g. Hasil yang diperoleh sejalan dengan penelitian Nguyen (2015) bahwa flavonoid tumbuhan kelubut memiliki komponen senyawa aktif tertinggi pada fraksi etil asetat.

Aktivitas antioksidan ditentukan dengan metode penangkapan radikal (radical scavenging) menggunakan radikal DPPH. Pengukuran aktivitas antioksidan dengan metode ini berdasarkan pada kemampuan suatu senyawa uji untuk mengurangi intensitas warna radikal DPPH pada $515 \mathrm{~nm}$ (Rohman, 2007). Metode uji aktivitas antioksidan dengan DPPH (1,1-diphenyl-2-picrylhydrazyl) dipilih karena metode ini adalah metode sederhana, mudah, cepat dan peka serta hanya memerlukan sedikit sampel untuk evaluasi aktivitas antioksidan dari senyawa bahan alam sehingga digunakan secara luas untuk menguji kemampuan senyawa yang berperan sebagai pendonor elektron (Molyneux, 2004). Hasil 
penentuan aktivitas antioksidan ekstrak dan atau fraksi daun mengkudu dapat dilihat pada Tabel 1

Tabel 1. Hasil Uji Aktivitas Antioksidan

\begin{tabular}{cc}
\hline Sampel & IC50 \\
\hline Ekstrak Metanol & 237.68 \\
Fraksi Etil asetat & 648.912 \\
Fraksi n-heksana & 105.840 \\
Fraksi n-butanol & 140.300 \\
\hline
\end{tabular}

Berdasarkan tabel hasil uji aktivitas antioksidan fraksi etil asetat daun kelubut memiliki aktivitas antioksidan yang lebih tinggi jika dibandingkan dengan aktivitas antioksidan ekstrak metanol, fraksi n-heksana dan fraksi n-butanol. Hal ini diduga karena kandungan senyawa antioksidan pada fraksi etil asetat tersebut telah mengalami pengelompokkan senyawa berdasarkan sifat kelarutannya pada proses fraksinasi sehingga memiliki aktivitas antioksidan paling tinggi dibandingkan dalam ekstrak daun kelubut lainnya. Rendahnya aktivitas antioksidan pada fraksi n-heksana dapat diduga karena senyawa yang terkandung didalamnya tidak mempunyai aktivitas antioksidan.

Salah satu faktor yang mempengaruhi aktivitas antioksidan ialah faktor substrat yaitu sifat antioksidan yang ditimbulkan oleh kandungan fitokimia yang terkandung dalam sampel. Senyawa golongan fenolik diketahui sangat berperan terhadap aktivitas antioksidan, semakin besar kandungan senyawa golongan fenolnya maka semakin besar aktivitas antioksidannya (Hardiana et al., 2012) sedangkan Pokorni et al dalam Sunarni et al (2007) menyatakan bahwa flavonoid dengan gugus hidroksi bebas mempunyai aktivitas penangkap radikal dan adanya gugus hidroksi lebih dari satu terutama pada cincin B akan meningkatkan aktivitas antioksidannya.

\section{KESIMPULAN}

1. Kandungan senyawa flavonoid tertinggi terdapat pada fraksi etil asetat sebesar 5.44 mg QE/g, diikuti fraksi n-butanol, ekstrak metanol dan fraksi nheksana berturut-turut sebesar $2.31 \mathrm{mg} \mathrm{QE} / \mathrm{g}, 1.72 \mathrm{mg} \mathrm{QE} / \mathrm{g}$ dan $0.936 \mathrm{QE} / \mathrm{g}$ 
2. Aktivitas antioksidan ekstrak daun kelubut dengan nilai $\mathrm{IC}_{50}$ tertinggi terdapat pada fraksi etil asetat dengan konsentrasi 105.840 ppm.

\section{DAFTAR PUSTAKA}

Anwar Khoerul dan Liling Triyasmono. 2016. Kandungan Total Fenolik, Total Flavonoid, dan Aktivitas Antioksidan Ekstrak Etanol Buah Mengkudu (Morinda citrifolia L.). Jurnal Pharmascience. Vol. 3. No. 1.

Assadujjaman, et al. 2014. Medicinal Potential of Passiflora foetida L. Plant Extracts: Biological and Pharmacological Activities. Journal of Integrative Medicine. 12(2): 121-126.

Azizah, Dyah Nur, Endang Kumolowati dan Fahrauk Faramayuda. 2014. Penetapan Kadar Flavonoid Metode Alcl3 Pada Ekstrak Metanol Kulit Buah Kakao (Theobroma cacao L.). Jurnal Ilmiah Farmasi. 2 (2) 45-49.

Dewi et al., 2014. Aktivitas Antioksidan Senyawa Flavonoid Ekstrak Etanol Biji Terong Belanda (Solanum betaceum, syn) dalam Menghambat Reaksi Peroksidasi Lemak pada Plasma Darah Tikus Wistar. Cakra Kimia (Indonesian E-Journal of Applied Chemistry). Vol.2. No.1.

Hardiana, Ricky, Rudiyansyah, Titin Anita Zaharah. 2012. Aktivitas Antioksidan Senyawa Golongan Fenol dari Beberapa Jenis Tumbuhan Famili Malvaceae. JKK. Vol.1 (1).

Manarim, GR dan De Agular. 2016. Removal of Pigments from Sugarcane Cells by Adsorbent Chromatographic Column. Ann Chromatogr Sep Tech. 2(1): 1015.

Maulana, Egy Azikin, I. A. R. Astiti Asih, dan Made Arsa. 2016. Isolasi dan Uji Aktivitas Antioksidan Senyawa Flavonoid dari Ekstrak Daun Jambu Biji Putih (Psidium guajava Linn). Jurnal Kimia. Vol. 10(1): 161-168.

Molyneux, Philip. 2004. The Use Of The Stable Free Radical Diphenylpicrylhydrazyl (DPPH) for Estimating Antioxidant Activity. Songklanakarin J. Sci. Technol. Vol. 26 No. 2.

Nguyen, Thi Yen, Dao Chung Tuo dan Manh Hung Tran. 2015. Anti-inflammatory Flavonoids Isolated from Passiflora foetida. Natural Product Communication. Vol. 10 No. 6: 929-931.

Rohman, et al., 2007. Aktivitas Antioksidan, Kandungan Fenolik Total dan Flavonoid Total Daun Mengkudu (Morinda citrifolia L). Agritech. Vol. 27. No. 4.

Sunarni, Titiek, Suwidjiyo Pramono dan Ratna Asmah. 2007. Flavonoid Antioksidan Penangkap Radikal Dari Daun Kepel (Stelechocarpus burahol (B1.) Hook F. \& Th.). Majalah Farmasi Indonesia. 18(3): 111116.

Zhu, H., Wang, Y.Z., Liu, Y.X. and Xia, Y.L. 2009. Analysis of flavonoids in Portulaca oleracea L. by UV-Vis spectrophotometry with comparative study on different extraction technologies. In Food Analytical Methods. Springer Science.

Zou, Zhuo, Wanpeng Xi, Yan Hu, Chao Nie dan Zhiqin Zhou. 2015. Antioxidant Activity of Citrus fruits. Food Chemistry. Elsevier. 